\title{
Pathogenesis of experimentally induced bacterial cold water disease in ayu Plecoglossus altivelis
}

\author{
Satoshi Miwa*, Chihaya Nakayasu
}

Inland Station, National Research Institute of Aquaculture, Fisheries Research Agency, Tamaki, Mie 519-0423, Japan

\begin{abstract}
Ayu Plecoglossus altivelis were experimentally infected with Flavobacterium psychrophilum, which is the causative agent of bacterial cold water disease (CWD). The fish infected by immersion usually died within an hour after they became moribund. The blood volume and haematocrit values of moribund fish were low, while those values of many infected fish that were not moribund were in the range of controls. Most of the affected fish in the immersion-infected groups had ulcerative lesions on their lower jaw. No histological evidence of haemolysis was observed. These results suggest that rapid bleeding occurred through ulcerative lesions, probably causing hypoxia which killed the fish. Ulcerative lesions developed on the dorsal skin when this area had been slightly abraded artificially prior to immersion challenge. Histologically, F. psychrophilum was initially found on the skin that had microscopic injuries, but not on normal skin. The bacterium then entered the dermis and migrated through connective tissues. The lesions subsequently expanded into the underlying musculature through the myosepta, developed necrotic myositis and formed externally open ulcers. Only in later stages of infection did mild lesions develop in the internal organs and the gill, probably caused by the bacterium migrating through blood vessels. This suggests that infection with CWD through the gill or digestive tract is unlikely. Virtually no open lesions were found in ayu challenged by intramuscular injections except at the injection sites. The results suggest that skin injuries are major portals of entry for F. psychrophilum in ayu, and the bacterium has affinity for collagenous connective tissues.
\end{abstract}

KEY WORDS: Cold water disease · Flavobacterium psychrophilum • Pathogenesis · Ayu · Plecoglossus altivelis

Resale or republication not permitted without written consent of the publisher

\section{INTRODUCTION}

Flavobacterium psychrophilum is the causative agent of bacterial cold water disease (CWD) and has been recognized as a serious problem in freshwater aquaculture worldwide, particularly for salmonid fishes (Nematollahi et al. 2003). In Japan, CWD in ayu Plecoglossus altivelis has been occurring since 1987 (Wakabayashi et al. 1994). Ayu are highly prized in Japan not only as a delicacy but also as a game fish. According to the statistics by the Ministry of Agriculture, Forestry and Fisheries, the amount of money yielded by ayu fisheries and farming comprises onethird of the total value of the production of freshwater fisheries in Japan. Ayu are osmerid fish having a life span of only 1 yr. Many are amphidromous, but there are also some landlocked populations. Many rivers are stocked extensively with juvenile ayu every year for recreational angling. The landlocked population of Lake Biwa had been the single dominant source of juvenile ayu for stocking and farming until the mid 1990s. Therefore, once the ayu in Lake Biwa were infested with F. psychrophilum, the disease spread rapidly throughout Japan, although it is not known when the bacteria entered the lake. Since then, CWD has been a serious problem in fishing and farming of ayu.

CWD of ayu has some different characteristics from those of CWD in salmonid fishes. Local fisheries research stations throughout Japan report that the disease generally occurs in early summer when water temperature is 16 to $18^{\circ} \mathrm{C}$. This is in contrast with 
salmonids in which the disease occurs most frequently when the water temperature is between 4 and $10^{\circ} \mathrm{C}$ (Shotts \& Starliper 1999). The most notable clinical sign of CWD in ayu is anaemia as revealed by pale gills (Iida \& Mizokami 1996). Ulcerative lesions are often found on the caudal peduncle of affected wild ayu, including stocked fish (Iida \& Mizokami 1996). However, when CWD occurs in cultured ayu, ulcerative lesions on the surface of the body trunk are often not observed, although haemorrhagic lesions or ulcers develop on the lower jaw of many of the affected fish. The ulcerative lesions found on the caudal peduncle of affected wild ayu might develop following infection by the bacteria into skin wounds caused by fishing (snagging) or by territorial aggression by other ayu. Erosion of fins (fin rot) or tail loss, which are typical clinical signs for CWD in salmonids (Nematollahi et al. 2003), are not observed in ayu. Furthermore, the F. psychrophilum strain(s) that causes CWD in ayu is distinct serologically and genetically from those in other fish species including salmonids (Izumi \& Wakabayashi 1999, Izumi et al. 2003, Tabata 2004). However, the pathogenesis of the disease in ayu has not been studied so far.

In the present study, we infected cultured ayu with $F$. psychrophilum experimentally, recorded clinical signs and confirmed the development of anaemia by measuring haematocrit and blood volumes. In a second experiment, we produced the ulcerative lesions on the dorsal skin by making a slight abrasion prior to immersion infection. The progression of the disease was then studied histopathologically. In a third experiment, to prove that the lesions on the body surface were caused by the bacteria attaching to the skin directly from the outside of the body, we infected fish with either immersion or intramuscular injection and confirmed that the lesions on the body surface do not develop in the injection-challenged fish.

\section{MATERIALS AND METHODS}

Fish and experimental conditions. Juvenile ayu were obtained from a private hatchery (Nisshin Marine Tech), where no CWD incidence had occurred, and transported to the Inland Station of National Research Institute of Aquaculture (NRIA; Tamaki, Mie prefecture, Japan). The first batch of 1000 fish was obtained in February 2003 and their average body weight was $1.1 \mathrm{~g}$. The second batch of 500 fish was obtained in April 2004 and the average body weight was $1.0 \mathrm{~g}$. The fish were fed commercial diet and reared in a $500 \mathrm{l}$ tank, aerated and supplied with running freshwater at 15 to $17^{\circ} \mathrm{C}$ until they grew to the size at which the experiments were possible $(>2 \mathrm{~g}$ ). After transfer to the
NRIA, ayu were reared for $104 \mathrm{~d}$ before Expt 1, for $77 \mathrm{~d}$ before Expt 2, and for $100 \mathrm{~d}$ before Expt 3. In all the experimental infections in the present study, the fish were kept in round tanks that were $34 \mathrm{~cm}$ in diameter. Each tank contained about $15 \mathrm{l}$ of aerated, running fresh water at 16 to $17^{\circ} \mathrm{C}$ during the experiments.

Bacteria. The Flavobacterium psychrophilum strain FPSG011227 was obtained from Shiga Prefectural Fisheries Research Station and used for all experimental infections. This strain was originally isolated from ayu in Shiga prefecture and the identity was confirmed by PCR for small subunit ribosomal RNA (Toyama et al. 1994). The genotype of the bacterium was B-S (Izumi et al. 2003). The bacterium was cultured with modified cytophaga (MCY) broth (Wakabayashi \& Egusa 1974; $0.2 \%$ tryptone, $0.05 \%$ yeast extract, $0.02 \%$ beef extract, $0.02 \%$ sodium acetate, $0.02 \%$ sodium chloride) at $15^{\circ} \mathrm{C}$, centrifuged at $15000 \times g$ for $10 \mathrm{~min}$, and the supernatant was replaced with fresh broth. Glycerol was then added to the culture at $10 \%$, and $500 \mu \mathrm{l}$ aliquots were stored at $-80^{\circ} \mathrm{C}$. For each experimental infection, an aliquot of the stored bacteria was newly thawed, and $10 \mu$ lof the aliquot was mixed in $3 \mathrm{ml}$ of MCY broth and cultured for $24 \mathrm{~h}$ at $15^{\circ} \mathrm{C}$ with shaking. The culture was then added to 11 of MCY broth and further cultured for $24 \mathrm{~h}$ at $15^{\circ} \mathrm{C}$ with shaking and then used for the challenges. The number of bacteria was estimated from the broth before dilution into the immersion bath by counting colonies on MCY agar (MCY broth $+1.2 \%$ agar) plates inoculated with 10-fold serial dilutions.

Expt 1. For the bacterial challenge, 80 fish were put into a bucket containing $9 \mathrm{l}$ of aerated water to which the culture of Flavobacterium psychrophilum in 11 of MCY broth was added. The estimated number of bacteria in the challenge bath was $1.6 \times 10^{8} \mathrm{CFU}$ (colony forming units) $\mathrm{ml}^{-1}$. The fish were thus exposed to the bacterium for $2 \mathrm{~h}$ and subsequently divided into 4 experimental tanks, each of which contained 20 fish. For the control, 40 fish were immersed in water containing MCY broth at $10 \%$ without F. psychrophilum for $2 \mathrm{~h}$. These were divided into 2 experimental tanks containing each 20 fish. Thus, a total of 120 fish were used for this experiment. The body weight of the fish used in this experiment was $3.30 \pm 0.74 \mathrm{~g}$ (average and standard deviation). Fish in both groups were reared by feeding commercial diet ad libitum. The fish in the experimental tanks were observed at $1 \mathrm{~h}$ intervals during daytime every day, and moribund or lethargic fish were sampled. The first moribund fish was sampled on Day 2, and the last one was sampled on Day 6. The caudal peduncle of the sampled fish was cut with a scalpel and as much blood as possible was immediately withdrawn into heparinized capillaries. The capillaries were centrifuged for $5 \mathrm{~min}$ at $15000 \times g$ and the 
volume of sampled blood and haematocrit values were measured. The external clinical signs were recorded for all dead or moribund fish. All of the surviving fish in the challenged groups and 10 fish from each of the control groups were sampled on Day 6, and their blood volume and haematocrit values were measured similarly. The fish were anaesthetized with 2-phenoxyethanol before blood sampling except for the moribund fish.

Expt 2. Abrasion: Prior to infection, ayu were anaesthetized with 2-phenoxyethanol and each fish was abraded as shown in Fig. 1. The abrasion made in this way could not be seen with the naked eye. Histological observations revealed that the epidermis of the abraded dorsal skin was either completely missing or only the outer layers of the epidermis were removed. A preliminary study revealed that open lesions developed on the abraded skin in more than half of the fish challenged (Fig. 2).

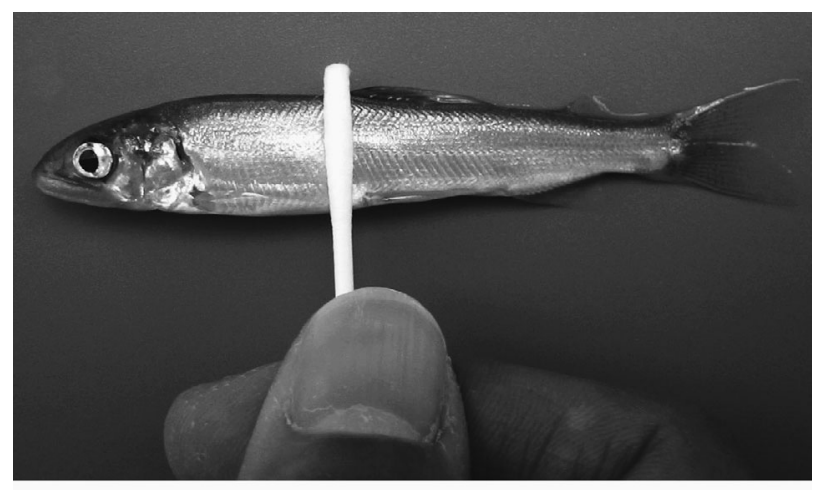

Fig. 1. Plecoglossus altivelis. The skin was abraded by turning a new sterilized swab round while softly pushing it onto the dorsal skin just prior to immersion challenge

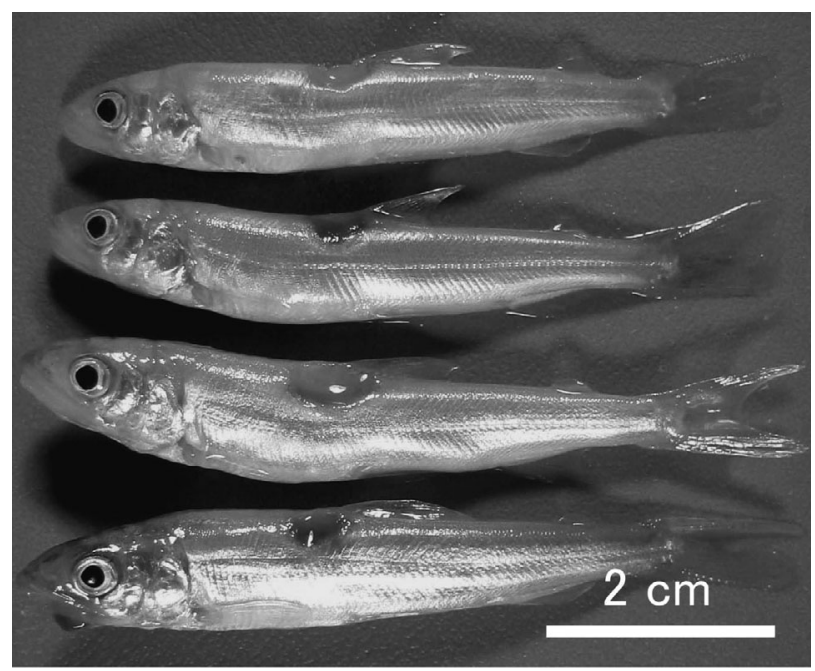

Fig. 2. Plecoglossus altivelis. Open ulcers developed at the sites of artificial abrasion in the fish challenged with Flavobacterium psychrophilum in a preliminary experiment
Experimental infection and fish sampling: The fish with abraded skin were challenged with the bacterium as described in the method for Expt 1. The body weight of the fish used in this experiment was $2.50 \pm 0.52 \mathrm{~g}$ (average and standard deviation). The estimated number of bacteria in the challenge bath was $2.0 \times 10^{8} \mathrm{CFU}$ $\mathrm{ml}^{-1}$. Ten fish were immediately subjected to histological sampling after the challenge. The remaining fish were divided into 5 experimental tanks so that the tanks contained 13 (Tank 1), 17 (2), 20 (3), 20 (4), and 25 (5) fish respectively, and the fish in the tanks were sampled in this order. This was because we tried to keep the number of ayu in each tank minimal in order to avoid sampling weakened individuals selectively. At the same time, however, to keep enough numbers of fish for sampling, the initial numbers of fish placed in the tanks were increased as the tank numbers increased because mortality was also expected to increase as the disease progressed. Ten fish were sampled $1 \mathrm{~d}$ after challenge from Tank 1, and 10 fish were similarly sampled 2, 3, and $5 \mathrm{~d}$ after challenge from Tanks 2, 3, and 4, respectively. Sampling was terminated $5 \mathrm{~d}$ after challenge since a high mortality was observed on Day 4. On Day 5, only 9 fish remained in Tank 4, and hence 1 fish was sampled from Tank 5 on this day. Fish were fed commercial diet ad libitum. In addition to these fish, 10 fish were similarly abraded on the skin and sampled for histology without exposure to the bacteria. Thus, 115 fish were used in total and 60 fish were subjected to histology in this experiment.

Histology: Each fish was anesthetized and the following tissues or organs were excised: the snout (upper jaw); the lower jaw; the rest of the head for the observations of the brain and gill; the heart with surrounding tissues; the visceral organs for the observations of the liver, spleen, stomach, intestine, and pancreas; and parts of the body for the observations of the abraded skin and kidney. The tissues were fixed overnight in Davidson's solution (330 ml 95\% ethanol, $220 \mathrm{ml} \mathrm{com-}$ mercial formaldehyde solution containing $37 \%$ formaldehyde and $8 \%$ methanol, $115 \mathrm{ml}$ glacial acetic acid, and $335 \mathrm{ml}$ distilled water). The fixed tissues were then decalcified in $0.1 \mathrm{M}$ PBS (phosphate buffered saline, pH 7.4) containing 300 mM EDTA for $4 \mathrm{~d}$ and embedded in paraffin. The tissue blocks were sectioned at $3 \mu \mathrm{m}$. The snout was sectioned along the median plane. The lower jaw was sectioned transversely at 2 different places. The dorsal skin with the artificial abrasion was also cut transversely. The sections were duplicated and stained with May-Grünwald Giemsa (MG) or analysed by immunocytochemistry for Flavobacterium psychrophilum antigens. When the bacterial antigen was detected by immunocytochemistry, the presence of bacterial cells was always checked in the same region with MG-stained sections at high magnification. 
Antiserum for immunocytochemistry: Rabbit polyclonal antibody was raised against Flavobacterium psychrophilum. F. psychrophilum (the same strain as used for the experimental infections) was killed with $0.3 \%$ formalin, washed with PBS, and used as the antigen. The killed bacterium $\left(1.3 \times 10^{8} \mathrm{CFU}\right)$ was injected into a rabbit subcutaneously with complete Freund adjuvant. The rabbit was given 3 booster shots each of the same amount of the antigen on Days 14, 28 and 42, and the serum obtained $52 \mathrm{~d}$ after the first injection was used for the present study.

Immunocytochemistry: Deparaffinized sections were treated with normal goat serum diluted to $1 / 20$ with $10 \mathrm{mM}$ PBS (pH7.4) for $30 \mathrm{~min}$, then incubated with the primary antiserum against Flavobacterium psychrophilum at 1/1000 dilution with 10 mM PBS containing 1\% BSA (Bovine serum albumin fraction \#5, Sigma) for $1 \mathrm{~h}$. Subsequently the slides were washed with PBS and incubated with goat anti-rabbit IgG labeled with horseradish peroxidase (BioSource International) diluted to $1 / 200$ with $10 \mathrm{mM}$ PBS containing $1 \%$ BSA. The slides were then washed with PBS and treated with $50 \mathrm{mM}$ Tris- $\mathrm{HCl}(\mathrm{pH}$ 7.6) containing $0.02 \% \quad 3,3$-diaminobenzidine tetrahydrochloride (Dojindo) and $0.03 \% \mathrm{H}_{2} \mathrm{O}_{2}$ for $5 \mathrm{~min}$. The slides were lightly counterstained with haematoxylin. A preliminary experiment showed that there was no endogenous peroxidase activity in the tissue sections. The primary antiserum was replaced with PBS in negative controls.

Expt 3. Fish were challenged in 2 different ways. For the immersion infection, 40 fish were challenged as in Expt 1. The estimated number of bacteria in the challenge bath was $6.0 \times 10^{7} \mathrm{CFU} \mathrm{ml}{ }^{-1}$. These fish were divided into 2 experimental tanks containing 20 fish each. For the control, 21 fish were immersed in water containing MCY broth as described previously, and reared in an experimental tank. Another 40 fish were used for the injection challenge. Each fish was anesthetized with 2-phenoxyethanol, and injected with bacteria at $1.5 \times 10^{5} \mathrm{CFU} 25 \mathrm{\mu l}^{-1}$ fish $^{-1}$ into the dorsal musculature. These fish were divided into 2 experimental tanks. For the control, 21 fish were injected with similarly diluted MCY broth without bacteria, and reared in an experimental tank. The body weight of the fish used in this experiment was $3.34 \pm 0.46 \mathrm{~g}$ (average and standard deviation). Several fish that were given the injections, including those of the control group, started to have convulsions immediately after the injection, and 3 of those fish died in 1 experimental tank on the day of the challenge. These fish were not included in the number of fish subjected to the experiment. Thus, the initial numbers of fish in the 2 injection-challenged groups were 20 and 17 , and a total of 119 fish were used in this experiment. Three fish had a convulsion in the control group, and they died during the experiment. The injections were made deep inside the fish trunk body close to the vertebral column to prevent leakage of the inoculum. Hence, the inoculum may have physically pressed the spinal cord and thereby caused a convulsion in the fish. The inoculum may have also entered into the spinal fluid in some fish. During the experiment, moribund fish were sampled, and blood volume and haematocrit values were measured as in Expt 1. The clinical signs or macroscopic lesions were recorded for dead or moribund fish. On Day 11, the remaining fish were sampled and the experiment was terminated. The blood volume and haematocrit were measured similarly for those fish.

\section{RESULTS}

\section{Expt 1}

The total mortality was $2.5 \%$ for the control groups ( $\mathrm{n}=40$ ), and $56 \%$ (including the moribund fish sampled for blood) for the challenged groups $(n=80)$. Challenged fish were often found to be dead despite the observations at $1 \mathrm{~h}$ intervals, and only 10 moribund fish were sampled throughout the experiment. The clinical signs observed in the moribund or dead fish are summarized in Table 1. Haemorrhage in the pericardium was not checked in this experiment. The results of the blood analyses are summarized in Fig. 3.

\section{Expt 2}

The total mortality other than the fish used for histology sampling was $65 \%$ during the experiment. In many cases, the antigen of Flavobacterium psychro-

Table 1. Plecoglossus altivelis. Clinical signs observed in dead or moribund fish infected with Flavobacterium psychrophilum by immersion challenge in Expt 1

\begin{tabular}{|lc|}
\hline Clinical signs & $\%(\mathrm{n})$ \\
\hline $\begin{array}{l}\text { Anaemia (judged either by pale gill or } \\
\text { blood analyses) }\end{array}$ & $96(43)$ \\
$\begin{array}{l}\text { Haemorrhage, ulcer, or erosion of } \\
\text { the lower jaw }\end{array}$ & $87(39)$ \\
$\begin{array}{l}\text { Haemorrhage in the fins or at the base } \\
\text { of the fins }\end{array}$ & $58(26)$ \\
$\begin{array}{l}\text { Haemorrhage, ulcer, or erosion of } \\
\text { the upper jaw or snout }\end{array}$ & $38(17)$ \\
$\begin{array}{l}\text { Haemorrhage in the eye } \\
\text { Haemorrhage in the head }\end{array}$ & $36(16)$ \\
Erosion of the edge of the fins & $31(14)$ \\
Total & $4(2)$ \\
\end{tabular}




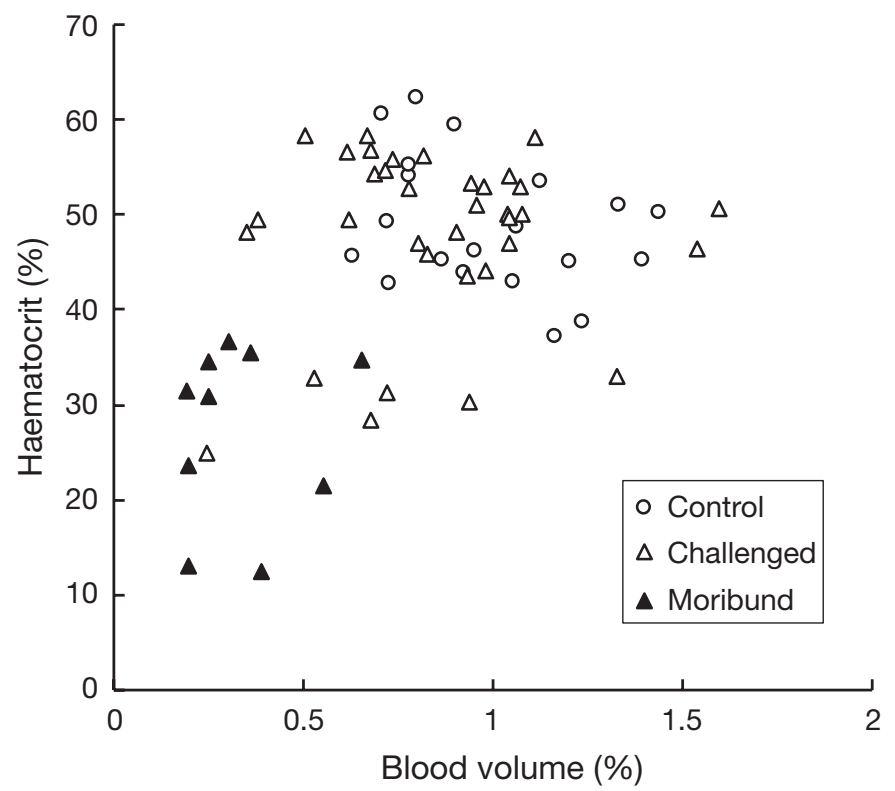

Fig. 3. Plecoglossus altivelis. Blood volume (\% of body weight assuming that the density of the blood is $1 \mathrm{~g} \mathrm{ml}^{-1}$ ) and haematocrit values of ayu challenged with Flavobacterium psychrophilum by immersion. (O) Control fish immersed in the diluted MCY broth without bacteria and sampled after $6 \mathrm{~d}$. $(\triangle)$ Fish immersed in the diluted MCY broth containing bacteria at $1.6 \times 10^{8} \mathrm{CFU} \mathrm{ml}{ }^{-1}$ and sampled after $6 \mathrm{~d}$. (ט) Fish exposed to $F$. psychrophilum and sampled when they were moribund ial antigen. In the fish sampled without challenge, neither the bacterium nor any immunocytochemical reaction was found.

\section{Skin lesions}

The epidermis of the abraded dorsal skin was either completely missing or only superficially removed, whereas the dermis remained intact. In most of the fish examined, the epidermis of the lower surface of the lower jaw also had similar microscopic abrasions as observed in the dorsal skin that had been artificially abraded. The skin of the snout of some fish also had such abrasions.

In the tissues sampled immediately after challenge, the bacterium was observed on the dermis at the artificial abrasion on the dorsal skin (Fig. 4a) and at spontaneous abrasions on the lower jaw where the epidermis was missing (Fig. 4b). Some bacteria were also found inside the dermis. Many bacteria were often observed in the scale pockets at the abrasion sites. Bacteria were also found on the epidermis where the outermost squamous cells were missing. No bacteria were found on the normal skin. In the fish sampled $1 \mathrm{~d}$ after challenge, numerous Flavobacterium psychrophilum cells were found in the dermis or in the connective tissue philum was detected by immunocytochemistry even without bacterial cells, and bacterial cells were often not clearly distinguished by immunocytochemistry, particularly when bacteria were inside connective tissue. Bacteria observed in tissue sections were thin rods (approximately 0.2 to $0.3 \times 2 \mu \mathrm{m}$ ), and always positive with immunocytochemistry, and hence identified as Flavobacterium psychrophilum. No other type of bacterium was observed in the tissue sections except in the lumen of the digestive tract. No macroscopic clinical sign was observed in the visceral organs. Ulcerative lesions on the body surface were formed either on the lower jaw, snout (upper jaw), or at the site of artificial abrasion. No apparent open lesion was found on the other parts of the body surface. No apparent necrotic lesions were observed in the brain, heart, kidney and visceral organs throughout the experiment. Table 2 summarizes the results of the histological detection of bacteria or the bacter-
Table 2. Plecoglossus altivelis. Histological detection of Flavobacterium psychrophilum cells or the antigen in experimentally infected fish by immersion in Expt 2. Data are number of fish in which free F. psychrophilum cells were observed/number of fish in which antigen was detected. The 'antigen' includes that which was detected in phagocytes in blood vessels. Tissues from 10 fish were observed for each sampling unless otherwise indicated

\begin{tabular}{|lccccc|}
\hline \multirow{2}{*}{ Tissue } & \multicolumn{5}{c|}{ Days after challenge } \\
& 0 & 1 & 2 & 3 & 5 \\
\hline Abraded skin (open surface) & $6 / 10$ & $3 / 9$ & $4 / 9$ & $3 / 9$ & $4 / 8$ \\
Abraded skin (dermis) & $1 / 1$ & $9 / 9$ & $9 / 9$ & $10 / 10$ & $6 / 9$ \\
Muscle tissue under the abrasion & $0 / 0$ & $3 / 5$ & $8 / 9$ & $8 / 8$ & $6 / 8$ \\
Lower jaw (open surface) & $9 / 10$ & $2 / 9$ & $1 / 9$ & $2 / 10$ & $3 / 9$ \\
Lower jaw (connective tissues) & $0 / 2$ & $10 / 10$ & $8 / 10$ & $6 / 10$ & $5 / 10$ \\
Snout (open surface) & $6 / 8$ & $0 / 1$ & $2 / 2$ & $1 / 4$ & $1 / 1$ \\
Snout (connective tissues) & $1 / 1$ & $4 / 4$ & $5 / 5$ & $6 / 7$ & $3 / 8$ \\
Skin of other part of the body & $1 / 3$ & $1 / 1$ & $0 / 1$ & $0 / 1$ & $0 / 0$ \\
Stomach lumen & $7 / 9^{\mathrm{a}}$ & $2 / 7^{\mathrm{a}}$ & $1 / 4$ & $3 / 5$ & $2 / 6$ \\
Lamina propria of the gastric glands & $0 / 0^{\mathrm{a}}$ & $0 / 0^{\mathrm{a}}$ & $0 / 1$ & $2 / 8$ & $1 / 4^{\mathrm{c}}$ \\
Intestinal lumen & $1 / 10$ & $2 / 8$ & $1 / 3$ & $1 / 3$ & $0 / 4$ \\
Lamina propria of intestine & $0 / 0$ & $0 / 0$ & $0 / 1$ & $1 / 8$ & $2 / 5$ \\
Spleen & $0 / 0$ & $0 / 1$ & $1 / 6^{\mathrm{b}}$ & $8 / 8$ & $4 / 8^{\mathrm{a}}$ \\
Kidney & $0 / 0$ & $0 / 1$ & $0 / 6$ & $3 / 9$ & $0 / 6^{\mathrm{a}}$ \\
Heart (either atrium or ventricle ) & $0 / 0$ & $0 / 1$ & $0 / 4$ & $3 / 8^{\mathrm{a}}$ & $3 / 6$ \\
Liver & $0 / 0$ & $0 / 0$ & $0 / 5$ & $0 / 9$ & $0 / 6$ \\
Pancreas & $0 / 0$ & $0 / 0$ & $0 / 0$ & $0 / 4$ & $0 / 0$ \\
Gill or Pseudobranch & $0 / 0$ & $0 / 0$ & $0 / 4$ & $0 / 6^{\mathrm{b}}$ & $2 / 6$ \\
Body cavity & $0 / 0$ & $0 / 0$ & $0 / 0$ & $0 / 0$ & $0 / 3$ \\
Bone & $0 / 0$ & $1 / 1$ & $0 / 0$ & $1 / 1$ & $0 / 0$ \\
a9 fish, b8 fish, and ${ }^{\mathrm{c}} 6$ fish were observed & & & & & \\
\hline
\end{tabular}




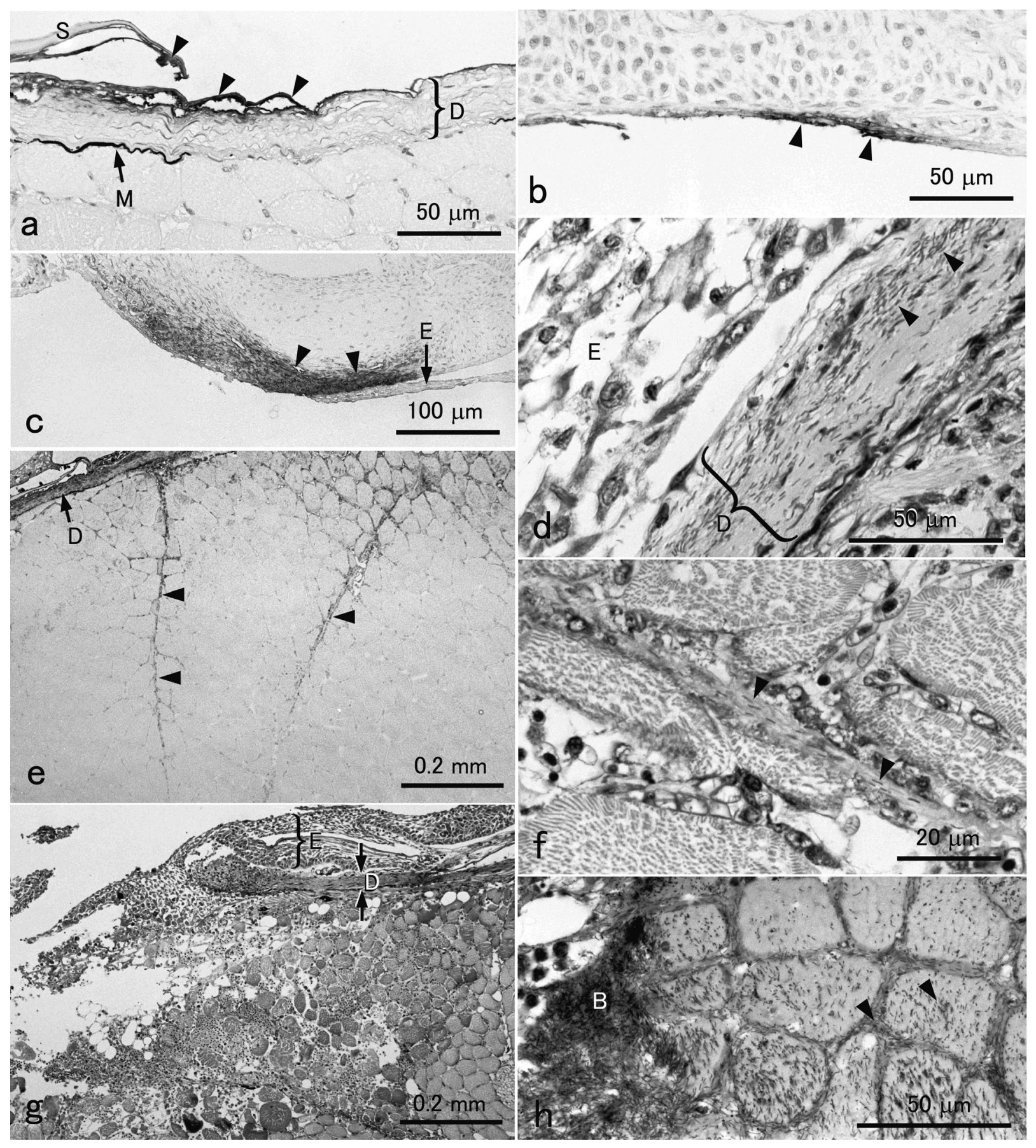

Fig. 4. Plecoglossus altivelis infected with Flavobacterium psychrophilum. Histological sections stained with May-GrünwaldGiemsa $(\mathrm{d}, \mathrm{f}, \mathrm{g}, \mathrm{h})$ or showing immunocytochemistry $(\mathrm{a}, \mathrm{b}, \mathrm{c}, \mathrm{e})$ against $F$. psychrophilum. (a) Artificial abrasion on the dorsal skin immediately after exposure to the bacterium. The epidermis is missing and the bacterial antigen (arrowheads) is observed on the dermis (D). $\mathrm{S}=$ scale; $\mathrm{M}=$ melanophore. (b) Bacterial antigen (arrowheads) on the lower jaw immediately after exposure to the bacterium. The epidermis is missing. (c) The bacterial antigen (arrowheads) in the connective tissue of the lower jaw $1 \mathrm{~d}$ after challenge. E = epidermis. (d) Many F. psychrophilum cells (arrowheads) in the dermis (D) $1 \mathrm{~d}$ after challenge. Note the absence of bacteria in the epidermis (E) which is highly oedematous. (e) Distribution of the bacterial antigen along the myosepta (arrowheads) $2 \mathrm{~d}$ after challenge. $\mathrm{D}=$ dermis. (f) F. psychrophilum cells (arrowheads) in the connective tissue of a myoseptum $2 \mathrm{~d}$ after challenge. Haemorrhaging is occurring in the surrounding muscular tissue. $(\mathrm{g})$ Severe necrotic myositis in the ulcer developed on the artificially abraded skin $3 \mathrm{~d}$ after challenge. The dermis (D) and epidermis (E) are missing in the upper left-hand corner. (h) F. psychrophilum cells (B) in the muscle tissue at the ulcerative lesion developed at the artificial abrasion $3 \mathrm{~d}$ after challenge. Many bacteria are found surrounding or inside muscle fibers (arrowheads) 
under the epidermis (Fig. 4c,d). Inflammatory cells often accumulated around the infection sites, although in most of the cases the bacterial antigen was not observed in those cells.

On Day 2, lesions such as erosion of a small area of the skin, haemorrhage, or slight bulging were observed at the sites of artificial abrasion in 7 fish. The dermis of the infection sites was often swollen, containing numerous bacteria, whereas virtually no free bacteria were observed in the epidermis, although the epidermis at the lesions was always oedematous. Bacteria were also found in the muscle layer under the abraded skin, particularly along the myosepta (Fig. 4e,f). Numerous inflammatory cells accumulated at the infection sites where haemorrhage was often observed. The bacterial antigen or bacterial cells were often found in many of these inflammatory cells which were presumably phagocytes such as neutrophils and macrophages.

On Day 3, necrotizing myositis was often observed in the centre of the lesion (Fig. 4g). In some of the lesions, large numbers of bacteria were seen surrounding or inside the muscle fibres (Fig. 4h). In severe cases, the dermis and myosepta were virtually replaced by bacterial masses and the dermis in the centre of the lesions was often lost. Extensive haemorrhage was also observed in these lesions. The bacterial invasion and inflammation also proceeded deeply into the connective tissues of the lower jaw or the snout of several fish and the tissues were often sloughed in these lesions.

On Day 5, ulcers were found at the sites of artificial abrasion in 7 fish. Either haemorrhage or sloughing of tissue was observed in the lower jaw of 6 fish. The erosion of the tissues generally became more severe in these lesions. In 2 fish, however, only a small number of free bacteria were observed in the ulcerative lesions, although numerous leucocytes with bacteria or the bacterial antigen in their cytoplasm were seen (Fig. 5a).

\section{Digestive tract}

Many Flavobacterium psychrophilum cells were found in the stomach lumen immediately after immersion. However, the bacterium was detected in the intestinal lumen in only 1 fish, although the bacterial antigen was found in the lumen of the intestine and pyloric caeca in all fish examined (Fig. 5b). Bacterial cells or the bacterial antigen were always observed in the stomach or intestinal lumen of some fish. Inside the organs, the bacterial antigen was usually first detected along the blood vessel wall in lamina propria (Fig. 5c). Bacterial cells were also found in lamina propria in some fish although no clear morphological lesions were observed. No F. psychrophilum directly attached to the epithelial cells, and no bacteria were found in the epithelium throughout the experiment. In the stomach lumen of 2 fish, fragments of muscle fibers infested with many F. psychrophilum cells were observed on Day 5 (Fig. 5d,e).

\section{Other organs}

Neither bacteria nor bacterial antigen were observed in the brain. Bones and cartilage were free from bacteria even when severe lesions developed in the surrounding connective tissues except for 2 cases in which small numbers of bacteria were found in the periphery of bones. In the other organs, as in the digestive tract, the bacterial antigen began to appear along the wall of blood vessels on Day 2, and bacterial cells were most frequently observed on Day 3 (Table 2). In some fish sampled on Days 2 and 3, the bacterial antigen was diffusely localized in the lumen of blood vessels. Small numbers of leucocytes containing the bacterial antigen in their cytoplasm were first observed in some fish $1 \mathrm{~d}$ after the challenge. On Day 2, many of these cells appeared in the kidney and spleen, and in the blood vessels of the other internal organs including heart and liver. These cells were continually observed on Days 3 and 5 in most of the fish. The bacterial antigen in the liver parenchyma was first found on Day 3. The antigen was found along the endothelium of the sinusoids, or in unidentified cells along the sinusoids in most of the fish (Fig. 5f). In some fish observed on Days 3 and 5, hepatocytes themselves contained the bacterial antigen which was confined to a certain compartment in the cytoplasm. In the spleen, the bacterial antigen, and bacteria were observed in the connective tissue of ellipsoids (Fig. 5g,h). Many free bacteria were observed in the ellipsoids on Day 3, although no apparent necrotic lesion was observed. Many leucocytes with strong reaction of the bacterial antigen were found in the kidney of 6 fish on Day 2, and small numbers of free bacteria were observed on Day 3. Except for migrating leucocytes in the lumen, the bacterial antigen was first detected in the tissues of the heart on Day 3. Mild inflammation of the cardiac muscle and the atrial wall was observed in some fish on Days 3 and 5 (Fig. 5i,j). However, the numbers of bacteria observed in these lesions were very small and no apparent necrotic lesion was found. In the gill or pseudobranch, bacteria were found around the blood vessels or around the cartilage in the gill of some fish on Days 3 and 5. Focal hyperplasia of the gill epithelium was found in these tissues (Fig. 5k). In most of the organs, the intensity of the antigen reaction and the numbers of bacteria generally decreased on Day 5 . 


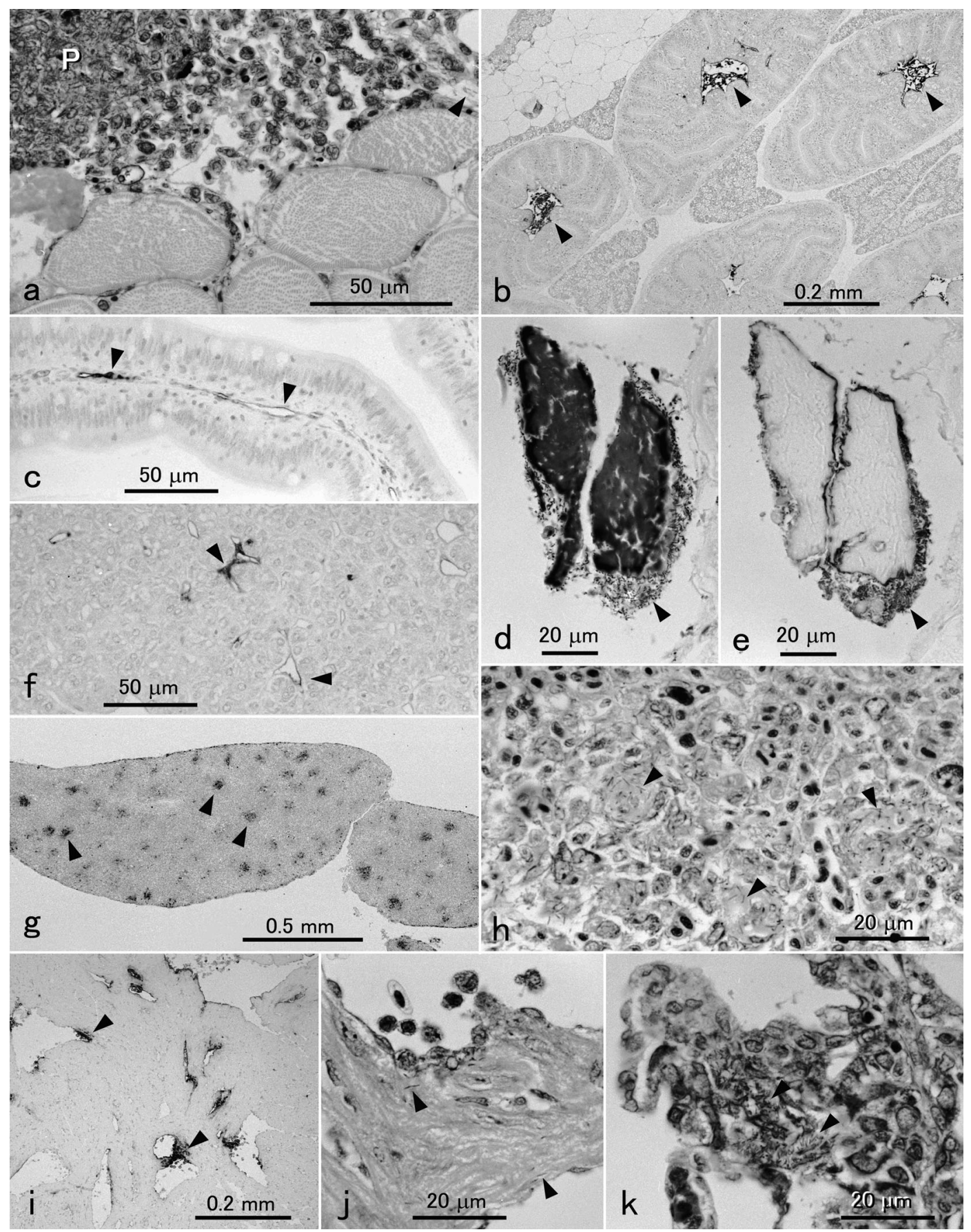

Fig. 5. Plecoglossus altivelis infected with Flavobacterium psychrophilum. Histological sections stained with May-GrünwaldGiemsa $(\mathrm{a}, \mathrm{d}, \mathrm{h}, \mathrm{j}, \mathrm{k})$ or showing immunocytochemistry $(\mathrm{b}, \mathrm{c}, \mathrm{e}, \mathrm{f}, \mathrm{g}, \mathrm{i})$ against $F$. psychrophilum. (a) Ulcerative lesion formed at the artificial abrasion $5 \mathrm{~d}$ after challenge. Numerous phagocytes (P) containing bacteria are observed. Virtually no bacteria are found in the muscle fibers, although some free bacteria (arrowhead) are seen. (b) Bacterial antigen (arrowheads) found in the lumen of the pyloric caeca immediately after challenge. (c) Bacterial antigen (arrowheads) found along the wall of the blood vessels in lamina propria of the intestine $5 \mathrm{~d}$ after challenge. (d) F. psychrophilum (arrowhead) attached to fragments of muscle fibers in the stomach lumen $5 \mathrm{~d}$ after challenge. (e) The same muscle fragments and bacteria (arrowhead) shown in d. (f) Bacterial antigen (arrowheads) found along the wall of the sinusoids in the liver of a fish $3 \mathrm{~d}$ after challenge. $(\mathrm{g})$ The spleen of a fish $3 \mathrm{~d}$ after challenge. Bacterial antigen (arrowheads) is located on ellipsoids. (h) F. psychrophilum cells (arrowheads) in the ellipsoids of the spleen. (i) Bacterial antigen (arrowheads) found in the ventricle $5 \mathrm{~d}$ after challenge. (j) Mild myositis found in the same tissue as that shown in (i). A few bacterial cells are seen (arrowheads). (k) A lesion formed on the gill $5 \mathrm{~d}$ after challenge. Note focal hyperplasia of the gill epithelium and the bacteria (arrowheads) 
Table 3. Plecoglossus altivelis. Numbers of dead or moribund fish infected with Flavobacterium psychrophilum either by injection or immersion in Expt 3. Tanks were duplicated for each challenge method. The number in parentheses after each group designation indicates the initial number of fish in the group

\begin{tabular}{|c|c|c|c|c|c|c|c|c|c|c|c|c|}
\hline & \multicolumn{11}{|c|}{ Days after challenge } & \multirow{2}{*}{$\begin{array}{c}\text { Total } \\
(\%)\end{array}$} \\
\hline & 1 & 2 & 3 & 4 & 5 & 6 & 7 & 8 & 9 & 10 & 11 & \\
\hline Injection - control (21) & 1 & & & $1^{\mathrm{a}}$ & 1 & & 1 & & & & & $4(19)$ \\
\hline Injection -1 (20) & & $1^{\mathrm{a}}$ & $1^{\mathrm{b}}$ & $12^{\mathrm{a}}$ & $3^{\mathrm{a}}$ & $1^{\mathrm{a}}$ & & & & & & $18(90)$ \\
\hline Injection -2 (17) & & & $3^{\mathrm{a}}$ & $12^{\mathrm{a}}$ & & & & & & & & $15(88)$ \\
\hline Immersion - control (21) & & & & 1 & & & & & & & & $1(5)$ \\
\hline Immersion -1 (20) & & $1^{b}$ & & $8^{\mathrm{b}}$ & $2^{\mathrm{b}}$ & $3^{b}$ & $1^{\mathrm{a}}$ & $1^{\mathrm{b}}$ & & $1^{b}$ & $1^{\mathrm{a}}$ & $18(90)$ \\
\hline Immersion -2 (20) & & $1^{b}$ & $2^{b}$ & $3^{\mathrm{b}}$ & & $1^{\mathrm{b}}$ & $4^{\mathrm{b}}$ & $2^{\mathrm{b}}$ & $1^{b}$ & $1^{b}$ & & $15(75)$ \\
\hline
\end{tabular}

\section{Expt 3}

The mortalities and the appearances of lesions in the lower jaw are summarized in Table 3. Eighteen moribund or lethargic fish were sampled from injectionchallenged groups whereas only 5 moribund fish were sampled from immersion-challenged groups. This may be because that most of the mortality occurred in a much shorter period of time in the injection-challenged groups compared with the immersion-challenged

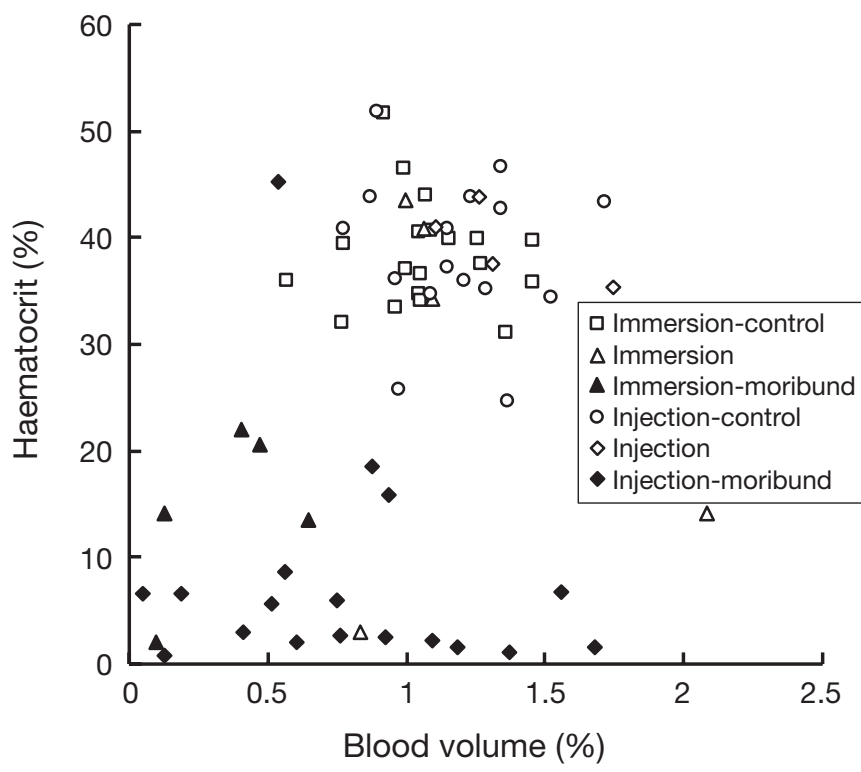

Fig. 6. Plecoglossus altivelis. Blood volume (\% of body weight assuming that the density of the blood is $1 \mathrm{~g} \mathrm{ml}^{-1}$ ) and haematocrit values of ayu challenged with Flavobacterium psychrophilum by either immersion or intramuscular injection. Fish were sampled $11 \mathrm{~d}$ after the challenge except for moribund fish. ( $\square$ ) Fish immersed in the diluted MCY broth without bacteria. $(\triangle)$ Fish immersed in the diluted MCY broth containing the bacterium at $6.0 \times 10^{7} \mathrm{CFU} \mathrm{ml}^{-1}$. (A) Fish immersed in the diluted MCY broth containing the bacterium and sampled when they were moribund. (O) Control fish injected with MCY broth without bacteria. $(\diamond)$ Fish injected with the bacterium at $1.5 \times 10^{5} \mathrm{CFU} \mathrm{fish}^{-1}$. ( $\bullet$ Fish injected with the bacterium and sampled when they were moribund

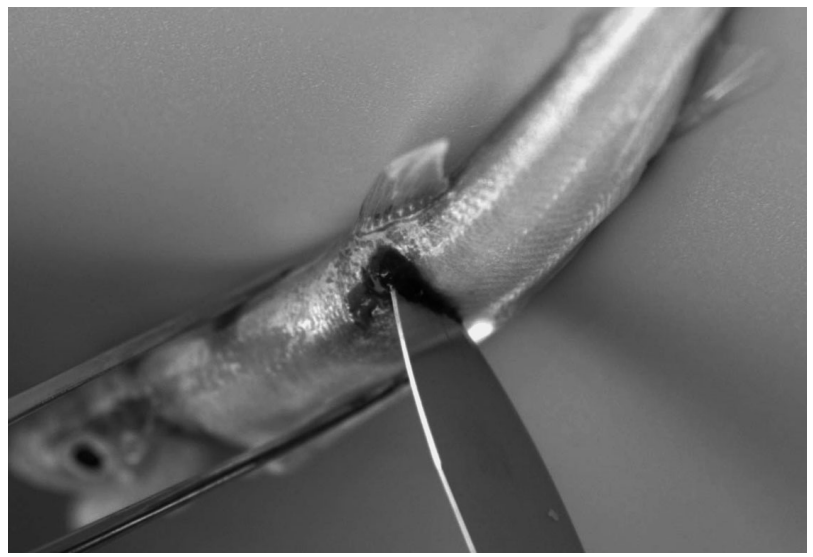

Fig. 7. Plecoglossus altivelis. A large haematoma revealed by incision with a scalpel at the site of intramuscular injection of Flavobacterium psychrophilum

groups. Anaemia was commonly observed in the dead or moribund fish, irrespective of the challenge methods of injection or immersion. However, the nature of the anaemia in the injection-challenged fish was somewhat different from that of the immersion-challenged fish. The blood volume and haematocrit values were both low in the moribund fish challenged with immersion, whereas the blood volume of several moribund fish in the injection-challenged groups was at the level of the control fish and only the haematocrit values were very low (Fig. 6). For the fish challenged with immersion, externally open lesions were found in the lower jaw and upper jaw and snout. Most of the dead or moribund fish challenged with injection, however, showed no open lesions on the skin except for the injection sites. The injection sites often bulged and appeared discoloured, and a large amount of blood accumulated in the muscular tissue (Fig. 7). The blood in these haematomas was not coagulated, and it often poured out from the injection site when the bulge was pressed. Haemorrhage in the pericardial cavity was observed in 1 fish challenged by injection and in 5 fish challenged with immersion. 


\section{DISCUSSION}

\section{Portals of entry}

The results of the present study suggest that Flavobacterium psychrophilum enters the body of ayu through injured skin. The bacterial entry into the body through healthy skin seems improbable since no bacterium or bacterial antigen was observed in the intact skin. The external lesions of CWD-affected ayu are most likely due to F. psychrophilum infection through already existing skin injuries. This is also supported by the virtual absence of ulcers or haemorrhagic lesions on the body surface of fish challenged with intramuscular injection except at the site of injection. This further suggests that ayu are unlikely to be infected with F. psychrophilum if the fish has no external injuries. Kondo et al. (2002) also reported the adherence of $F$. psychrophilum to the lower jaw and caudal peduncle where the epidermis had collapsed. The importance of mechanical injuries as the portals of entry of F. psychrophilum has already been suggested in salmonids. Although the experimental infection of F. psychrophilum through immersion is often difficult (Nematollahi et al. 2003), incision or removal of the mucus layer from the skin markedly enhances the susceptibility of rainbow trout to water-borne bacteria (Madetoja et al. 2000). Martinez et al. (2004) also reported that the ray axis of fins needs to be exposed by previous damage for the invasion of $F$. psychrophilum. Skin injuries are also important portals for some other bacterial infections of fish such as Aeromonas hydrophila infection in the channel catfish Ictalurus punctatus (Ventura \& Grizzle 1987). Small particles like bacteria can be passively attached to injured skin surface (Kiryu \& Wakabayashi 1999, Sukenda \& Wakabayashi 2001). The histological observations of the present study suggest that, once the bacterium adheres to the dermis, it enters the tissue quickly. However, it is not certain whether the bacteria attached to superficially injured epidermis can reach the dermis, since almost no free bacteria were observed in the epidermal tissue of the skin.

Most ayu used for the present experiments already had microscopic abrasions on the lower jaw, although these lesions could not be observed with the naked eye. The skin of the lower jaw was probably abraded when the fish scraped the wall or the bottom of the rearing tank with their teeth, which is a characteristic behavior of ayu. In spontaneously occurring CWD in cultured ayu, one of the clinical signs most often noted is lesions on the lower jaw. In the present study, no apparent lesions developed on the lower jaw when the fish were injected with the bacterium, and hence lesions on the lower jaw are most likely caused by direct infection with the bacterium on abraded skin, as discussed above. Thus, it is likely that cultured ayu typically have similar abrasions on the lower jaw, and that these abrasions are the major portals of F. psychrophilum infection for these fish.

The absence of bacteria in the gill or in the tissues of digestive tract until later stages of infection suggests that the bacterium does not infect ayu through these organs. This is in agreement with previous studies in which orally administered Flavobacterium psychrophilum could not reproduce the disease (Decostere et al. 2000, Madetoja et al. 2000). Although bacteria or the bacterial antigen were detected in these organs, it seems clear that these infections occurred from bacteria migrating through blood vessels, since the bacterial antigen or bacterial cells were first detected on the wall of blood vessels of these organs a few days after challenge. Many F. psychrophilum cells were observed in the stomach lumen immediately after the immersion challenge. In the intestinal lumen, however, bacterial cells were observed in only 1 fish, although the bacterial antigen was clearly detected in all fish examined. This suggests that most of the ingested bacteria were probably killed and digested in the stomach or intestine. In the stomach lumen of 2 fish sampled on Day 5, fragments of muscle fibres with a large number of immunoreactive bacterial cells were observed. This clearly suggests that these fish had bitten other fish on their lesions. Although infection through the digestive tract seems improbable, such fish can be infected with bacteria through injuries on the lower jaw.

\section{Affinity of the bacterium for tissues}

In the early stage of infection, Flavobacterium psychrophilum proliferated in the dermal connective tissue and seemed to migrate through the dermis and myosepta into the fish's body. In later stages, many bacteria were observed in the skeletal muscle fibres and some were found in cardiac muscle fibres. Free bacteria were seldom observed in epithelial tissues. These observations suggest not only the affinity of the bacterium for the collagenous connective tissues, but also the importance of direct access of the bacterium to such tissues through mechanical injuries to establish infection. Salmonid fishes affected with CWD also sometimes develop lesions similar to those found in ayu, such as ulcers on the skin or on the mouth (Dalsgaard 1993). For salmonid CWD, there is evidence that F. psychrophilum has affinity for hard tissues such as cartilage, bone or fin rays (Ostland et al. 1997). Ekman \& Norrgren (2003) also reported accumulation of F. psychrophilum on the vertebrae in 3 species of salmonids experimentally infected with CWD. CWD in 
salmonids is sometimes called 'fin rot' and one of the early signs of the disease is loss of fin-tip integrity (Shotts \& Starliper 1999). Martinez et al. (2004) reported that $F$. psychrophilum was present on the ossified axis of fin rays but not in the epidermis of the experimentally infected Atlantic salmon Salmo salar. They showed that the bacterium penetrated directly into the ray axis probably by secreting protease(s) that eroded the tissue matrix. Since the major organic matrix of bone is collagen and collagen is also one of the major organic components of the cartilage matrix, it seems probable that F. psychrophilum generally has an affinity for collagen. In fact, F. psychrophilum produces enzymes that degrade collagen (Ostland et al. 2000). Martinez et al. (2004) argues that the requirement for calcium for the activation of an extracellular protease of the bacterium is the reason for the preference of the bacterium for the fin rays in early phases of salmonid CWD. In the present study, small numbers of the bacterium were found in the periphery of bones in 2 cases. These were, however, rather exceptional, and bones or cartilages were usually intact even when there were severe lesions in surrounding connective tissues. Hence, there may be a difference in the requirement for calcium or in the preference for the collagen molecules between the proteases of F. psychrophilum strains causing CWD in ayu and those causing CWD in salmonids. In addition, F. psychrophilum seems to have a certain affinity for striated muscular tissues since mild myocarditis and severe necrotic myositis were found in the present study. Necrotic myositis was also reported in CWD-infected salmonids (Lumsden et al. 1996).

\section{Cause of death}

In the present study, anaemia was the most frequently observed clinical sign of spontaneous CWD in ayu. Anaemia is also one of the most notable clinical signs for CWD in salmonids (Nematollahi et al. 2003). In Expt 1, all moribund fish showed smaller blood volume and lower haematocrit values than those of the controls, while the blood volume and haematocrit values of many of the infected fish other than the moribund fish were in the range of the control group. Furthermore, fish died very quickly, less than $1 \mathrm{~h}$ after they became moribund. These observations suggest that at a certain stage of infection, the anaemia advanced very swiftly and killed ayu probably by hypoxia. This anaemia resulted most likely from bleeding through lesions on the fish body for the following reasons. First, it is improbable for aplastic anaemia to occur in such a short period of time. Besides, no apparent necrotic lesion was observed in the haematopoietic tissues in the present study. Second, no evidence suggests that haemolysis had occurred. If haemolysis was the major cause for the anaemia in such a short period of time as in the present experiments, jaundice should have been observed. For example, jaundice is clearly observed in bacterial haemolytic jaundice of yellowtail Seriola quinqueradiata in which the causative bacteria lyse erythrocytes in the peripheral blood (Sorimachi et al. 1993, Maeno et al. 1995). Hence, haemolysis by Flavobacterium psychrophilum does not seem to contribute substantially to the anaemia of CWD-affected ayu although $F$. psychrophilum seems to be able to lyse fish erythrocytes to a certain degree (Lorenzen et al. 1997). Third, the blood volume was decreased in the moribund or lethargic ayu. F. psychrophilum is known to produce an enzyme which degrades fibrinogen (Nematollahi et al. 2003), and this may inhibit blood coagulation in the ulcerative lesions. Inflammation of the atrial wall and haemorrhage observed in the pericardial cavity suggest that the heart also can be a site of bleeding in CWD-affected ayu. Considering that anaemia and external lesions are the most common clinical signs for spontaneous CWD in ayu, anaemia (and probably hypoxia) caused by bleeding from open lesions is also likely to be the cause of death for ayu affected spontaneously by CWD.

Anaemia was also observed in the injectionchallenged fish, although no apparent open lesion was formed. Unlike immersion-challenged fish, however, several moribund fish in the injection-challenged groups exhibited blood volumes comparable to those of the control fish, although their haematocrit values were very low. In many of the injection-challenged fish, large haematomas had developed at the site of the injection. These suggest that erythrocytes had somehow accumulated in this lesion and did not return to the circulation, thereby causing low haematocrit values, although the mechanism of this is uncertain. This condition was apparently caused by the injection of a large amount of bacteria deep inside the body of the fish and would never occur in spontaneous infections of CWD.

\section{Infection of internal organs and recovery from the disease}

Although many leucocytes containing bacterial antigen appeared in the internal organs on Day 2, the antigen or bacteria were not detected substantially until Days 3 and 5 in the spleen, heart, kidney and gill. For most of the internal organs, the bacterial antigen was first detected along the wall of blood vessels except for that in the migrating leucocytes. This suggests that these organs were infected with bacteria transported 
from skin lesions through the vascular system. Many free bacteria were observed in the ellipsoids of the spleen on Day 3, although no severe lesion was observed. Splenomegaly is one of the major clinical signs in spontaneous CWD in ayu (Iida \& Mizokami 1996) as well as in salmonids (Rangdale et al. 1999, Decostere et al. 2001, Ekman \& Norrgren 2003). In salmonid CWD, necrotic changes and the presence of many free bacteria in the spleen have been reported in affected fish (Rangdale et al. 1999, Ekman \& Norrgren 2003). Hence, severe histopathological changes may also appear in the spleen of ayu if the disease becomes more chronic.

On Day 5, some fish showed evidence of recovery from the disease. In these fish, many leucocytes with bacteria or the bacterial antigen were observed in skin ulcers, but only small numbers of free bacteria were found in the lesions and virtually no bacteria were found in the adjacent muscle fibres, suggesting that further expansion of the ulcers had ceased. In the present study, numerous leucocytes ingested Flavobacterium psychrophilum or its antigen. This seems to suggest the importance of phagocytosis by immune cells for defense against F. psychrophilum. Hepatocytes are probably involved in the processing of substances from broken bacterial cells, since the bacterial antigen was detected in the hepatocytes in later stages of infection. Thus, ayu may survive CWD if the immune system is well activated before severe bleeding occurs.

Acknowledgements. This study was supported in part by the Japanese Ministry of Agriculture, Forestry, and Fisheries.

\section{LITERATURE CITED}

Dalsgaard I (1993) Virulence mechanisms in Cytophaga psychrophila and other Cytophaga-like bacteria pathogenic for fish. Annu Rev Fish Dis 3:127-144

Decostere A, Lammens M, Haesebrouck F (2000) Difficulties in experimental infection studies with Flavobacterium psychrophilum in rainbow trout (Oncorhynchus mykiss) using immersion, oral and anal challenges. Res Vet Sci 69: 165-169

Decostere A, D'Haese M, Lammens M, Nelis H, Haesebrouck F (2001) In vivo study of phagocytosis, intracellular survival and multiplication of Flavobacterium psychrophilum in rainbow trout, Oncorhynchus mykiss (Walbaum), spleen phagocytes. J Fish Dis 24:481-487

Ekman E, Norrgren L (2003) Pathology and immunohistochemistry in 3 species of salmonids after experimental infection with Flavobacterium psychrophilum. J Fish Dis 26:529-538

Iida Y, Mizokami A (1996) Outbreaks of coldwater disease in wild ayu and pale chub. Fish Pathol 31:157-164

Izumi S, Wakabayashi H (1999) Further study on serotyping of Flavobacterium psychrophilum. Fish Pathol 34:89-90

Izumi S, Aranishi F, Wakabayashi H (2003) Genotyping of Flavobacterium psychrophilum using PCR-RFLP analysis.
Dis Aquat Org 56:207-214

Kiryu I, Wakabayashi H (1999) Adherence of suspended particles to the body surface of rainbow trout. Fish Pathol 34: 177-182

Kondo M, Kawai K, Kurohara K, Oshima S (2002) Adherence of Flavobacterium psychrophilum on the body surface of the ayu Plecoglossus altivelis. Microbes Infect 4:279-283

Lorenzen E, Dalsgaard I, Bernardet JF (1997) Characterization of isolates of Flavobacterium psychrophilum associated with coldwater disease or rainbow trout fry syndrome I: phenotypic and genomic studies. Dis Aquat Org 31:197-208

Lumsden JS, Ostland VE, Ferguson HW (1996) Necrotic myositis in cage cultured rainbow trout, Oncorhynchus mykiss (Walbaum), caused by Flexibacter psychrophilus. J Fish Dis 19:113-119

Madetoja J, Nyman P, Wiklund T (2000) Flavobacterium psychrophilum, invasion into and shedding by rainbow trout Oncorhynchus mykiss. Dis Aquat Org 43:27-38

Maeno Y, Nakajima K, Sorimachi M, Inui Y (1995) Pathological studies of jaundiced yellowtail, Seriola quinqueradiata. Fish Pathol 30:7-14

Martinez JL, Casado A, Enriquez R (2004) Experimental infection of Flavobacterium psychrophilum in fins of Atlantic salmon Salmo salar revealed by scanning electron microscopy. Dis Aquat Org 59:79-84

Nematollahi A, Decostere A, Pasmans F, Haesebrouck F (2003) Flavobacterium psychrophilum infections in salmonid fish. J Fish Dis 26:563-574

Ostland VE, McGrogan DG, Ferguson HW (1997) Cephalic osteochondritis and necrotic scleritis in intensively reared salmonids associated with Flexibacter psychrophilus. J Fish Dis 20:443-451

Ostland VE, Byrne PJ, Hoover G, Ferguson HW (2000) Necrotic myositis of rainbow trout, Oncorhynchus mykiss (Walbaum): proteolytic characteristics of a crude extracellular preparation from Flavobacterium psychrophilum. J Fish Dis 23:329-336

Rangdale RE, Richards RH, Alderman DJ (1999) Histopathological and electron microscopical observations on rainbow trout fry syndrome. Vet Rec 144:251-254

Shotts EB, Starliper CE (1999) Flavobacterial diseases: columnaris disease, cold-water disease and bacterial gill disease. In: Woo PTK, Bruno DW (eds) Fish diseases and disorders, Vol 3: Viral, bacterial and fungal infections. CABI Publishing, New York, p 559-576

Sorimachi M, Maeno Y, Nakajima K, Inouye K, Inui Y (1993) Causative agent of jaundice of yellowtail, Seriola quinqueradiata. Fish Pathol 28:119-124

Sukenda, Wakabayashi H (2001) Adherence and infectivity of green fluorescent protein-labeled Pseudomonas plecoglossicida to ayu Plecoglossus altivelis. Fish Pathol 36: 161-167

Tabata K (2004) Relationships of the infectivity of Flavobacterium psychrophilum between native fishes and released ayu Plecoglossus altivelis in a river. Nippon Suisan Gakkaishi 70:318-323 (in Japanese with English abstract)

Toyama T, Kita-Tsukamoto K, Wakabayashi H (1994) Identification of Cytophaga psychrophila by PCR targeted 16S ribosomal RNA. Fish Pathol 29:271-275

Ventura MT, Grizzle JM (1987) Evaluation of portals of entry of Aeromonas hydrophila in channel catfish. Aquaculture 65:205-214

Wakabayashi H, Egusa S (1974) Characteristic of myxobacteria associated with some freshwater fish diseases in Japan. Bull Jpn Soc Sci Fish 40:751-757

Wakabayashi H, Toyama T, Iida T (1994) A study on serotyping of Cytophaga psychrophila isolated from fishes in Japan. Fish Pathol 29:101-104 